\title{
MENCERMATI KONSEP ISLAMISASI ILMU ISMAIL R FARUQI
}

\author{
A Khudori Soleh \\ Fakultas Psikologi UIN Maliki Malang, Jl. Gajayana 50 Malang, Telp. 0341- \\ 558916, email: khudori_uin@yahoo.com
}

\begin{abstract}
The idea of alFaruqi's Islamization of knowledge is a respon to the negative impact arising from the advances of modern science, and a priori attitudes of Muslims to the progress of science. This idea is created based on 5 basic principles: the oneness of God, the unity of creation, the unity of truth, unity of life and the unity of human. The purpose of this movement are: to mould a scholar who is (1) expert in modern science, (2) expert in the treasure of Islamic science, (3) understands the relevance of Islam with modern science, (4) able to integrate Islamic sciences with modern science creatively, (5) directs the Islamic thoughts to the God's plan. Therefore, to achieve these purposes, Al Faruqi makes 12 strategic moves which enable the student to: (1) be an expert in modern science, (2) analyzes modern science, (3) masters the Islamic sciences, (4) analyzes Islamic science, (5) understands the relevance of Islamic science to modern science, (6) be a critical analyst of modern science, (7) be a critical analyst of Islamic science, (8) Surveys the problems faced by Muslims, (9) surveys the problems faced by human, (10) be a creative synthesis, (11) writes the result of integration, (12) socialize.

Ide Islamisasi alFaruqi tentang pengetahuan merupakan respon terhadap dampak negatif yang timbul dari kemajuan ilmu pengetahuan modern, dan sikap apriori umat Islam untuk kemajuan ilmu pengetahuan. Ide ini dibuat berdasarkan 5 prinsip dasar: keesaan Tuhan, kesatuan penciptaan, kesatuan kebenaran, kesatuan hidup dan kesatuan manusia. Tujuan dari gerakan ini adalah: untuk cetakan seorang sarjana yang (1) ahli dalam ilmu pengetahuan modern, (2) ahli dalam harta ilmu pengetahuan Islam, (3) memahami relevansi Islam dengan ilmu pengetahuan modern, (4) mampu mengintegrasikan ilmu Islam dengan ilmu pengetahuan modern kreatif, (5) mengarahkan pemikiran Islam untuk rencana Allah. Oleh karena itu, untuk mencapai tujuan ini, al
\end{abstract}


Faruqi membuat 12 langkah strategis yang memungkinkan siswa untuk: (1) menjadi ahli dalam ilmu pengetahuan modern, (2) analisis ilmu pengetahuan modern, (3) menguasai ilmu-ilmu Islam, (4) analisis Islam ilmu pengetahuan, (5) memahami relevansi ilmu pengetahuan Islam untuk ilmu pengetahuan modern, (6) menjadi seorang analis kritis ilmu pengetahuan modern, (7) menjadi seorang analis kritis ilmu pengetahuan Islam, (8) Survei masalah yang dihadapi oleh umat Islam, (9) survei permasalahan yang dihadapi oleh manusia, (10) menjadi sintesis kreatif, (11) menulis hasil integrasi, (12) bersosialisasi

Keywords: Islam, modern and Islamization

\section{Pendahuluan}

Salah satu tokoh utama dalam program Islamisasi ilmu, khususnya di Amerika, adalah Ismael Raji alFaruqi. Ia bahkan telah menjadi ikon program ini lewat pendidikan tinggi yang dibangunnya tahun 1981 di Washington DC, yaitu The International Institue of Islamic Thought (IIIT). Tulisan ini akan mendiskusikan dan mencermati gagasan Islamisasi ilmu Faruqi tersebut yang dilakukan dengan 12 langkah kerja.

\section{Biografi Singkat Raji alFaruqi}

Ismail Raji alFaruqi lahir pada 1 Januari 1921 M, di Jaffa, Palestina, sebelum wilayah ini diduduki Israel (Azra, 1996: 49). Pendidikan awalnya ditempuh di College des Ferese, Libanon, yang menggunakan bahasa Prancis sebagai bahasa pengantarnya, kemudian di American University, Bairut, jurusan Filsafat. Pada tahun 1941, setelah meraih Bachelor of Arts (BA), ia bekerja sebagai pegawai pemerintah (PNS) Palestina di bawah mandat Inggris. Empat tahun kemudian, karena kepemimpinannya yang menonjol, Faruqi diangkat sebagai gubernur di propinsi Galelia, Palestina, pada usia 24 tahun. Namun, jabatan ini tidak lama diembannya, karena tahun 1947, propinsi tersebut jatuh ke tangan Israel, sehingga ia hijrah ke Amerika, setahun kemudian (Ridwan, 1995: 334; Lamya, 1997: xii).

Setahun di Amerika, Faruqi melanjutkan studinya di Universitas Indiana sampai meraih gelar master dalam bidang filsafat, tahun 1949. Dua tahun kemudian ia meraih gelar master kedua dalam bidang yang sama dari Universitas Harvard. Puncaknya, tahun 1952, Faruqi meraih gelar Ph.D dari Universitas Indiana, dengan disertasi berjudul On Justifying the God: Metaphysic and Epistemology of Value (tentang pembenaran Tuhan,metafisika dan epsitemologi nilai) (Lamya, 1997: xii). Namun, apa yang dicapai ini tidak memuaskannya. Karena itu, ia kemudian pergi ke Mesir untuk lebih mendalami ilmu-ilmu 
keislaman di Universitas alAzhar, Kairo (Azra, 1996: 49).

Pada tahun 1959, Faruqi pulang dari Mesir dan mengajar di McGill, Montreal, Kanada, sambil mempelajari Yudaisme dan Kristen secara intensif. Namun, dua tahun kemudian, 1961, ia pindah ke Karachi, Pakistan, untuk ambil bagian dalam kegiatan Central Institute for Islamic Research (CIIR) dan jurnalnya, Islamic Studies. Dua tahun di Pakistan, tahun 1963, Faruqi kembali ke Amerika dan mengajar di School of Devinity, Universitas Chicago, sambil melakukan kajian keislaman di Universitas Syracuse, New York. Selanjutnya, tahun 1968, Faruqi pindah dan menjadi guru besar pemikiran dan kebudayaan Islam pada Temple University, Philadelphia. Di sini Faruqi mendirikan Departemen Islamic Studies sekaligus memimpinnya sampai akhir hayatnya, 27 Mei 1986 (Faruqi, 1999: 274; Fauzi, 1996: 48-57).

Di samping kontribusinya yang besar dalam memperkenalkan studistudi keislaman di berbagai perguruan tinggi di Amerika dan proyeknya yang terkenal, 'islamisasi ilmu pengetahuan' (islamization of knowledge), Faruqi juga aktif dalam gerakan-gerakan keislaman dan keagamaan. Bersama istrinya, Dr. Louis Lamya, ia membentuk kelompok-kelompok kajian Islam, seperti Muslem Student Association (MSA), American Academy of Religion (AAR), mendirikan Himpunan Ilmuan Sosial Muslim (The Association of Muslem Social Scientist AMSS), Islamic Society of North America (ISNA), menerbitkan jurnal American Journal of Islamic Social Sciences (AJISS), dan yang menomental, mendirikan Perguruan Tinggi Pemikiran Islam (The International Institue of Islamic Thought -IIIT) (Azra, 1996: 50; Lamya, 1997: xii).

Selain itu, Faruqi juga duduk sebagai penasehat serta ikut mendesain program studi Islam di berbagai Universitas di dunia Islam, antara lain, di Pakistan, India, Afrika Selatan, Malaysia, Saudi Arabia dan Mesir. Juga di tempat-tempat_solative seperti di Universitas Mindanau, Philipina Selatan, dan Universitas Qum, Teheran, Iran (Lamya, 1997: ix).

Faruqi banyak meninggalkan karya tulis. Tercatat tidak kurang dari 100 artikel dan 25 judul buku, yang mencakup berbagai persoalan, antara lain, etika, seni, sosiologi, kebudayaan, metafisika dan politik. Di antara bukunya adalah:

Ushûl alSyahyuniyah fi alDîn alYahûdi (1963), Historical Atlas of Religion of the World (1974), Islamic and Culture (1980), Islamization of Knowledge General Principles and Work plan (1982), Tauhid Its Implications for Thought and Life (1982), Cultural Atlas of Islam (1986), Christian Ethics, Trealogue of Abraham Faith, dan Atlas of Islamic Culture and Civilization (Basori, 1991: iv). 


\section{Latar Belakang Islamisasi.}

Menurut Faruqi, adalah fakta bahwa apa yang dicapai sains modern, dalam berbagai aspeknya merupakan sesuatu yang sangat menakjubkan. Namun, kemajuan tersebut ternyata juga memberikan dampak lain yang tidak kalah mengkhawatirkannya. Akibat dari paradigma yang sekuler, pengetahuan modern menjadi kering, bahkan terpisah dari nilai-nilai tauhid: suatu prinsip global yang mencakup lima kesatuan, yaitu keesatuan Tuhan, kesatuan alam, kesatuan kebenaran, kesatuan hidup dan kesatuan umat manusia (alFaruqi, 1995: 55). Jelasnya, sains modern telah lepas atau melepaskan diri dari nilainilai teologis (Pardoyo, 1993: 63).

Perceraian sains modern dari nilai-nilai teologis ini memberikan dampak negatif. Pertama, dalam aplikasinya, sains modern melihat alam beserta hukum dan polanya, termasuk manusia sendiri, hanya sebagai sesuatu yang bersifat material dan insidental yang eksis tanpa intervensi Tuhan. Karena itu, manusia bisa memperkosa dan mengeksploitir kekayaan alam tanpa memperhitungkan nilai-nilai spiritualitas. Kedua, secara metodologis, sains modern ini, tidak terkecuali ilmu-ilmu sosialnya, menjadi sulit diterapkan untuk memahami realitas sosial masyarakat muslim yang mempunyai pandangan hidup berbeda dari Barat (Nasution, 1992: 242).

Sementara itu, keilmuan Islam sendiri yang dianggap bersentuhan dengan nilai-nilai teologis, terlalu berorientasi pada religiusitas dan spiritualitas tanpa memperdulikan betapa pentingnya ilmu-ilmu sosial dan ilmu kealaman yang dianggap sekuler. Demi menjaga identitas keislaman dalam persaingan budaya global, para ilmuan muslim bersikap defensif dengan mengambil posisi konservatif-statis, yakni dengan melarang segala bentuk inovasi dan mengedepankan ketaatan fanatik terhadap syariah (fiqh produk abad pertengahan). Mereka menganggap bahwa syariah (fiqh) adalah hasil karya yang telah fixed dan paripurna, sehingga segala perubahan dan pembaharuan atasnya adalah penyimpangan dan setiap penyimpangan adalah sesat dan bid `ah. Mereka melupakan sumber utama kreatifitas, yakni ijtihad, bahkan mencanangkan ketertutupannya (al Faruqi, 1995: 41).

Sikap sebagian ilmuan muslim tersebut, pada akhirnya juga menimbulkan pemisahan wahyu dari akal, pemisahan pemikiran dari aksi dan pemisahan pemikiran dari kultur, sehingga menimbulkan stagnasi keilmuan dikalangan mereka (al Faruqi, 1995: 43). Artinya, dampak negatif yang terjadi dari sikapsikap "keras kepala" sebagian ilmuan Islam sendiri sesungguhnya tidak kalah membahayakannya dibanding apa yang ada dalam sains modern. Kenyataannya, 
menurut Faruqi, di sekolah, akademi maupun universitas, tidak pernah terjadi seperti sekarang di mana seorang ilmuan muslim begitu berani mengemukakan tesa-tesa yang bisa dianggap tidak Islami, dan tidak sehebat sekarang acuhnya pemuda muslim terhadap agamanya (al Faruqi, 1995: 12).

Bersamaan dengan itu, sistem dan model pendidikan Islam yang dianggap sebagai ujung tombak kemajuan, justru mendukung dan melestarikan tradisi keilmuan Islam yang stagnan. Menurut Faruqi (al Faruqi, 1995: 12), model pendidikan masyarakat Islam bisa dipolakan menjadi tiga kategori. Pertama, Sistem pendidikan tradisional yang hanya mempelajari ilmu-ilmu keislaman secara sempit, sisi hukum dan ibadah mahllah, yang dalam konteks Indonesia bisa ditunjukan pada model pendidikan salaf di pesantren. Kedua, sistem pendidikan yang lebih menekankan ilmu-ilmu sekular yang diadopsi secara mentah dari barat, yang dalam konteks Indonesia bisa ditunjukkan pada sistem pendidikan umum. Kedua sistem ini menimbulkan dualisme (split) dalam kepribadian masyarakat muslim. Alumnus pendidikan salaf (pesantren) cenderung bersikap konservatif-ekslusif dan antagonistik terhadap ilmu-ilmu modern yang sebenarnya sangat diperlukan, sementara sarjana pendidikan modern cenderung bersikap sekularistik-materialistik dan antagonistik terhadap ilmu-ilmu religius.

Di samping kedua sistem pendidikan tersebut, ketiga, ada sistem konvergensif yang memadukan kedua sistem yang ada. Sistem ini, di samping memberikan materi agama juga memberikan berbagai disiplin ilmu modern yang diadopsi dari barat. Namun, pencangkokan ini ternyata tidak dilakukan di atas dasar filosofis yang benar, tetapi semata hanya diberikan secara bersamasama, ilmu-ilmu agama dijejerkan dengan ilmu-ilmu umum (seperti yang ada di MAN, STAIN, IAIN dan UIN), sehingga tidak memberikan dampak positif pada mahasiswa. Apalagi kenyataannya, ilmu-ilmu tersebut sering disampaikan oleh dosen yang kurang mempunyai wawasan keislaman dan kemoderanan yang memadai (al Faruqi, 1995:12; Soleh, 1996).

Berdasarkan realitas seperti itu, menurut Faruqi, tidak ada cara lain untuk membangkitkan Islam dan menolong nestapa dunia, kecuali dengan mengkaji kembali kultur keilmuan Islam masa lalu, masa kini dan keilmuan modern barat sekaligus, untuk kemudian mengolahnya menjadi keilmuan yang rahmatan li alalamin, melalui apa yang disebut "islamisasi ilmu" yang kemudian disosialisasikan lewat sistem pendidikan Islam yang integratis (Sardar, 1998: 44). 


\section{Prinsip Dasar Islamisasi.}

Untuk membandingkan gagasannya tentang islamisasi ilmu, Faruqi meletakkan pondasi epistemologinya pada "prinsip tauhid" yang terdiri lima macam kesatuan (al Faruqi, 1995: 55; Lamya,1996: 43), yaitu:

1. Keesaan (kesatuan) Tuhan, bahwa tidak ada Tuhan selain Allah, yang menciptakan dan memelihara semesta. Implikasinya, berkaitan dengan pengetahuan adalah bahwa sebuah pengetahuan bukan untuk menerangkan dan memahami realitas sebagai entitas yang terpisah dari realitas absolut (Tuhan), melainkan melihatnya sebagai bagian yang integral dari eksistensi Tuhan. Karena itu, islamisasi ilmu mengarahkan pengetahuan pada kondisi analisa dan sintesa tentang hubungan realitas yang dikaji dengan hukum Tuhan (divine pattern), (al Faruqi,1981: 17).

2. Kesatuan ciptaan, bahwa semesta yang ada ini baik yang material, psikis, spasial (ruang), biologis, sosial maupun estetis, adalah kesatuan yang integral. Masing-masing saling kait dan saling menyempurnakan dalam ketentuan hukum alam (sunnatullah) untuk mencapai tujuan akhir tertinggi, Tuhan. Namun, bersamaan dengan itu, Dia juga menundukkan alam semesta untuk manusia, sehingga mereka bisa mengubah polanya dan mendayagunakannya demi kesejahtaraan umat (al Faruqi, 1995: 58). Berdasarkan hal ini, dalam kaitannya dengan islamisasi ilmu, maka setiap penelitian dan usaha pengembangan keilmuan harus diarahkan sebagai refleksi dari keimanan dan realisasi ibadah kepada-Nya. Ini berbeda dengan prinsip keilmuan barat, di mana sejak abad 15, mereka sudah tidak lagi berterima kasih pada Tuhan melainkan hanya pada dirinya sendiri dan untuk kepentingannya sendiri. Mereka memisahkan pengetahuan dari prinsip teologis dan agama (Hidayat, 1995: 113).

3. Kesatuan kebenaran dan pengetahuan. Kebenaran bersumber pada realitas, dan jika semua realitas berasal dari sumber yang sama, Tuhan, maka kebenaran tidak mungkin lebih dari satu. Apa yang disampaikan lewat wahyu tidak mungkin berbeda apalagi bertentangan dengan realitas yang ada, karena Dia-lah yang menciptakan keduanya. Faruqi merumuskan kesatuan kebenaran ini sebagai berikut, (1) bahwa berdasarkan wahyu, kita tidak boleh membuat klaim yang paradoksal dengan realitas. Pernyataan yang diajarkan wahyu pasti benar dan harus berhubungan dan sesuai dengan realitas. Jika terjadi perbedaan atau bahkan pertentangan antara temuan sains dan wahyu, seorang muslim harus mempertimbangkan kembali pemahamannya atas teks atau mengkaji ulang data-data penelitiannya. 
(2) Bahwa dengan tidak adanya kontradiksi antara nalar dan wahyu, berarti tidak ada satupun kontradiksi antara realitas dan wahyu yang tidak terpecahkan. Karena itu, seorang muslim harus terbuka dan senantiasa berusaha merekonsiliasikan antara ajaran agama dengan kemajuan Iptek. (3) Bahwa pengamatan dan penyelidikan terhadap semesta dengan bagianbagiannya tidak akan pernah berakhir, karena pola-pola Tuhan tidak terhingga. Betapapun mendalam dan banyaknya seseorang menemukan data baru, semakin banyak pula data yang belum terungkap. Karena itu, seorang muslim dituntut bersikap open minded, rasional dan toleran terhadap bukti dan penemuan baru (al Faruqi, 1995: 66).

4. Kesatuan hidup. Menurut Faruqi, kehendak Tuhan terdiri atas dua macam: (1) berupa hukum alam (sunnatullah) dengan segala regularitasnya yang memungkinkan diteliti dan diamati, materi; (2) berupa hukum moral yang harus dipatuhi, agama. Kedua hukum ini berjalan seiring, senada dan seirama dalam kepribadian seorang muslim. Konsekuensinya, tidak ada pemisahan antara yang bersifat spiritual dan material, antara jasmani dan ruhani (al Faruqi, 1995: 85).

5. Kesatuan manusia. Tata sosial Islam, menurut Faruqi (al Faruqi, 1995: 110), adalah universal, mencakup seluruh umat manusia tanpa terkecuali. Kelompok muslim tidak disebut bangsa, suku atau kaum melainkan umat. Pengertian umat bersifat trans lokal dan tidak ditentukan oleh pertimbangan geografis, ekologis, etnis, warna kulit, kultur dan lainnya, tetapi hanya dilihat dari sisi taqwanya. Meski demikian, Islam tidak menolak adanya klasifikasi dan stratifikasi natural manusia ke dalam suku, bangsa dan ras sebagai potensi yang dikehendaki Tuhan. Yang ditolak dan dikutuk Islam adalah faham ethnosentrisme, karena hal ini akan mendorong penetapan hukum, bahwa kebaikan dan kejahatan hanya berdasarkan ethnisnya sendiri, sehingga menimbulkan berbagai konflik antar kelompok (al Faruqi, 1995: 88). Kaitannya dengan islamisasi ilmu, konsep ini mangajarkan bahwa setiap pengembangan ilmu harus berdasar dan bertujuan untuk kepentingan kemanusiaan, bukan hanya kepentingan golongan, ras dan etnis tertentu.

\section{Tujuan dan Langkah Kerja}

Secara umum, Islamisasi ilmu Faruqi dimaksudkan sebagai respon positif terhadap realitas pengetahuan modern yang sekularistik di satu sisi dan Islam yang terlalu religious di sisi yang lain, dalam model pengetahuan baru yang 
utuh dan integral tanpa pemisahan di antara keduanya. Secara rinci, tujuan yang dimaksud adalah:

1. Penguasaan disiplin ilmu modern

2. Penguasaan khazanah warisan Islam.

3. Membangun relevansi Islam dengan masing-masing disiplin ilmu modern.

4. Mamadukan nilai-nilai dan khazanah warisan Islam secara kreatif dengan ilmu-ilmu modern.

5. Pengarahan aliran pemikiran Islam ke jalan-jalan yang mencapai pemenuhan pola rencana Allah (alFaruqi, 1995: 98).

Untuk merealisasikan tujuan-tujuan tersebut, Faruqi menyusun 12 langkah yang secara kronologis harus ditempuh (al Faruqi, 1995: 99);

1. Penguasaan disiplin ilmu modern, penguasaan kategoris. Pada langkah awal ini, disiplin-disiplin ilmu modern harus dipecah-pecah menjadi kategorikategori, prinsip-prinsip, metode, problema dan tema-tema. Penguraian tersebut harus mencerminkan daftar isi sebuah buku daras (pelajaran) dalam bidang metodologi disiplin-disiplin ilmu yang bersangkutan. Hasil uraian tersebut tidak hanya berbentuk judul-judul bab, tapi harus berbentuk kalimat-kalimat yang memperjelas istilah-istilah teknis, menerangkan kategori, prinsip, problem dan tema pokok disiplin-disiplin ilmu yang bersangkutan (al Faruqi, 1995: 99).

2. Survei disiplin ilmu. Pada tahap ini, setiap disiplin ilmu modern harus disurvei dan ditulis dalam bentuk bagan (skema) mengenai asalusul, perkembangan dan pertumbuhan metodologinya, keluasan cakupannya serta sumbangan pemikiran yang telah diberikan para tokoh utamanya. Bibliografi dengan keterangan yang memadai dari karya-karya terpenting di bidang ini harus pula dicantumkan sebagai penutup dari masing-masing disiplin ilmu (al Faruqi, 1995: 99). Tujuannya untuk memantapkan pamahaman muslim terhadap berbagai disiplin ilmu modern yang berkembang di Barat, sehingga mereka benar-benar mengetahui secara detail dan menyeluruh tentang kekurangan dan kelebihan disiplin-disiplin ilmu tersebut. Hasil survei yang berkualitas yang dilengkapi daftar pustaka dan footnote yang lengkap akan menjadi dasar pengertian bersama bagi para ahli yang hendak melakukan islamisasi ilmu.

3. Penguasaan khazanah Islam, sebuah antologi. Pada tahap ini, perlu dicari sampai sejauh mana khazanah Islam menyentuh dan membahas 
objek disiplin ilmu modern tertentu. Tujuannya agar dapat ditemukan relevansi di antara khazanah barat dan Islam. Ini penting, karena banyak ilmuan muslim didikan barat tidak mengenal khazanah Islam sendiri, kemudian mengangap bahwa khazanah keilmuan Islam tidak membahas disiplin ilmu yang ditekuni. Padahal, yang terjadi adalah bahwa ia tidak mengenal kategori-kategori khazanah ilmiah Islam yang digunakan oleh ilmuan muslim tradisional untuk mengklasifikasi objek disiplin ilmu yang ditekuninya (alFaruqi, 1995: 100).

4. Penguasaan khazanah ilmiah Islam tahap analisa. Tahap ini diadakan analisis terhadap khazanah Islam dengan latar belakang historis dan kaitannya dengan berbagai bidang kehidupan manusia. Analisa historis ini dapat memperjelas berbagai wilayah wawasan Islam itu sendiri. Namun, analisa ini tidak bisa dilakukan secara sembarangan. Harus dibuat daftar urut prioritas, dan yang paling penting adalah bahwa prinsip-prinsip pokok, masalah-masalah pokok dan tema-tema abadi, yakni tajuk-tajuk yang mempunyai kemungkinan relevansinya kepada permasalahan masa kini harus menjadi sasaran strategis penelitian dan pendidikan Islam (alFaruqi, 1995: 103). Tahap ini dimaksudkan untuk mendekatkan karya-karya khazanah Islam kepada para sarjana didikan barat, dan untuk mengenal lebih jauh tentang konstruksi khazanah Islam, sehingga diketahui secara lebih jelas jangkauan gagasannya sesuai dengan konteks masanya.

5. Penentuan relevansi Islam yang khas terhadap disiplin-disiplin ilmu. Pada tahap ini, hakekat disiplin ilmu modern beserta metode dasar, prinsip, problem, tujuan, hasil capaian dan segala keterbatasannya, semua dikaitkan dengan khazanah Islam. Begitu pula relevansi-relevansi khazanah Islam spesifik pada masing-masing ilmu harus diturunkan secara logis dari sumbangan mereka. Dalam hal ini, ada tiga hal yang harus dijawab. (1) Apa yang telah di sumbangkan oleh Islam, mulai dari al Quran hingga kaum modernis saat ini, kepada keseluruhan masalah yang dikaji disiplin-disiplin ilmu modern? (2) Seberapa besar sumbangan Islam tersebut dibanding ilmu-ilmu Barat? Sejauh mana tingkat pemenuhan, kekurangan serta kelebihan khazanah Islam dibanding wawasan dan lingkungan disiplin ilmu modern? (3) Jika ada bidang masalah yang sedikit disentuh, atau bahkan di luar jangkauan khazanah Islam, ke arah mana ilmuan Islam harus mengisi kekurangan, merumuskan kembali permasalahannya dan memperluas cakrawala wawasan disiplin ilmu tersebut? (al Faruqi, 1995: 104). 
6. Penilaian kritis terhadap disiplin keilmuan modern dan tingkat perkembangannya di masa kini. Setelah mendiskripsikan dan menganalisis berbagai sisi dan relevansi antara khazanah Islam dan Barat, sekarang melakukan analisa kritis terhadap masing-masing ilmu dilihat dari sudut Islam. Inilah langkah utama dalam Islamisasi ilmu. Di sini ada beberapa hal yang harus dijawab. Benarkah disiplin ilmu tersebut telah memenuhi visi pelopornya? Benarkah ini telah merealisasikan peranannya dalam upaya mencari kebenaran? Sudahkah disiplin ilmu tersebut memenuhi harapan manusia dalam tujuan hidupnya? Sudahkah ilmu tersebut mendukung pemahaman dan perkembangan pola ciptaan Ilahi yang harus direalisasikan? Jawaban atas berbagai persoalan ini harus terkumpul dalam bentuk laporan mengenai tingkat perkembangan disiplin ilmu modern dilihat dari perspektif Islam (al Faruqi, 1995: 105).

7. Penilaian kritis terhadap khazanah Islam dan tingkat perkembangannya dewasa ini. Yang dimaksud khazanah Islam adalah al Quran dan Sunnah. Namun, ini tidak berarti bahwa kedua sumber tersebut harus menjadi objek kritik atau penilaian. Transendensi al Quran dan normativitas sunnah adalah ajang yang tidak diperdebatkan. Akan tetapi, interpretasi muslim terhadap keduanya yang historis kontekstual boleh dipertanyakan, bahkan harus selalu dinilai dan dikritik berdasarkan prinsip-prinsip dari kedua sumber pokok tersebut. Relevansi pemahaman manusiawi tentang wahyu Ilahi diberbagai aspek persoalan manusia harus dikritik dari tiga sudut. (1) Wawasan Islam sejauh yang dapat ditarik dari sumber-sumber wahyu beserta bentuk kongkretnya dalam sejarah kehidupan Rasul, para sahabat dan keturunanya. (2) Kebutuhan krusial umat manusia saat ini. (3) Semua disiplin ilmu modern yang diwakili oleh disiplin ilmu tersebut. Jika khazanah Islam tidak relevan lagi, harus dilakukan koreksi terhadapnya dengan usaha-usaha yang sesuai masa kini. Sebaliknya, jika relevan, khazanah Islam perlu dikembangkan dan disosialisasikan (al Faruqi, 1995: 107).

8. Survei permasalahan yang dihadapi umat Islam. Setelah diadakan analisa secara kritis terhadap keilmuan modern maupun khazanah Islam, langkah berikutnya adalah mengadakan survei terhadap berbagai problem intern di segala bidang. Problem ekonomi, sosial dan politik yang sedang dihadapi dunia Islam ini sebenarnya tidak berbeda dengan gunung es dari kelesuhan moral dan intelektual yang terpendam. Untuk bisa mengidentifikasi semuanya dibutuhkan survei empiris dan analisa kritis secara konprehensif. 
Kearifan yang terkandung dalam setiap disiplin ilmu harus dimanfaatkan untuk memecahkan problem umat Islam. Tidak seorang muslimpun boleh membatasi ilmunya dalam satu titik yang hanya memuaskan keinginan intelektulitasnya, lepas dari realitas, harapan dan aspirasi umat Islam (al Faruqi, 1995: 109).

9. Survei permasalahan yang dihadapi manusia. Sebagian dari wawasan dan visi Islam adalah tanggung-jawabnya yang tidak terbatas pada kesejahteraan umat Islam, tetapi juga menyangkut kesejahteraan seluruh umat manusia di dunia dengan segala hiterogenitasnya, bahkan mencakup seluruh alam semesta (rahmat li alalamin) (QS, al Anbiya: 107). Dalam beberapa hal, umat Islam memang terbelakang dibanding bangsa lain, tetapi dari sisi ideologis, mereka adalah umat yang paling potensial dalam upaya proses integralisasi antara kesejahteraan, religius, etika dan material. Islam mempunyai wawasan yang diperlukan bagi kemajuan peradaban manusia untuk menciptakan sejarah baru di masa depan. Karena itu, ilmuan muslim harus terpanggil untuk berpartisipasi menghadapi problem kemanusiaan dan membuat solusi terbaik sesuai misi dan visi Islam (al Faruqi, 1995: 110).

10. Analisa sintesa kreatif dan sintesa. Setelah memahami dan menguasai semua disiplin ilmu modern dan disiplin keilmuan Islam tradisonal, menimbang kelebihan dan kelemahan masing-masing, mendeterminasikan relevansi Islam dengan dimensi-dimensi pemikiran ilmiah tertentu pada disiplin-disiplin ilmu modern, mengidentifikasi problem yang dihadapi umat Islam dalam lintasan sejarah sebagai hamba sekaligus khalifah, dan setelah memahami permasalahan yang dihadapi dunia, maka saatnya mencari lompatan kreatif untuk bangkit dan tampil sebagai protektor dan developer peradaban manusia. Sintesa kreatif yang akurat harus dibuat di antara ilmu-ilmu Islam tradisional dan disiplin ilmu-ilmu modern untuk dapat mendobrak stagnasi intelektual selama beberapa abad. Khazanah ilmu-ilmu Islam harus terkait dengan hasil-hasil ilmu modern dan harus mulai menggerakkan barisan depan pengetahuan sampai cakrawala lebih jauh dari apa yang bisa diprediksikan oleh ilmu modern. Sintesa kreatif ini harus mampu memberikan solusi tuntas bagi permasalahan dunia, di samping permasalahan yang muncul dari harapan Islam (al Faruqi, 1995: 111). Apa harapan Islam di setiap bidang kehidupan, dan bagaimana sintesa baru tersebut menggerakan umat Islam maupun umat manusia ke arah terwujudnya harapan tersebut? Jika diketahui relevansi 
ilmu-ilmu Islam untuk topik tertentu dan setelah diketahui pula ciri khas permasalahan yang dihadapi, pilihan mana yang harus diambil? Apa kriteria yang digunakan bahwa Islam relevan dengan persoalan yang dihadapi? Bagaimana metodenya? Bagaimana tata kerjanya, alat evaluasi dan pertanggung-jawaban atas teorinya?

11. Penuangan kembali disiplin ilmu modern ke dalam kerangka Islam, buku-buku dasar tingkat universitas. Secara operasional, para intelektual muslim tidak akan mencapai sepakat tentang solusi suatu persoalan, karena perbedaan backgraund masing-masing. Ini tidak dilarang bahkan dibutuhkan sehingga kesadaran mereka menjadi lebih kaya dengan berbagai macam pertimbangan. Secara faktual, umat Islam abad pertengahan mampu menciptakan dinamika karena Islam bisa menjadi wadah untuk menampung segala macam ide dan gagasan baru yang mempresentasikan nilai-nilai Ilahiyah. Berdasarkan wawasan-wawasan baru tentang makna Islam serta pilihan-pilihan kreatif bagi realisasi makna tersebut, maka ditulislah buku-buku daras untuk perguruan tinggi, dalam semua bidang ilmu. Inilah puncak dari gerakan islamisasi pengetahuan. Namun, penulisan buku-buku daras ini sendiri bukan pencapaian final, melainkan justru baru sebagai permulaan dari sebuah perkembangan peradaban Islam dimasa depan. Buku-buku daras hanya sebagai pedoman umum bagi perkembangan selanjutnya. Karena itu, essei-essei yang mencerminkan dobrakan pandangan bagi setiap topik dan cabang ilmu harus pula ditulis sebagai "wawasan latar belakang" atau "bidang relevansi" yang dari sana diharapkan akan muncul wawasan baru Islam bagi masing-masing cabang ilmu modern (al Faruqi, 1995: 113).

12. Penyebaran ilmu-ilmu yang telah diislamkan. Setelah disiplin ilmu modern bisa dituangkan secara baik dalam kerangka Islam, langkah terakhir adalah mendistribusikan karya-karya tersebut ke seluruh masyarakat Islam. Sebab, karya-karya yang berharga tersebut tidak akan berarti jika hanya dinikmati oleh orang-orang tertentu atau dalam kalangan terbatas (al Faruqi, 1995: 115).

Selain itu, untuk mempercepat program Islamisasi, pertama, perlu sering dilakukan seminar dan konferensi yang melibatkan berbagai ahli dalam bidang keilmuan untuk memecahkan persoalan disekitar pengkotaan antar disiplin ilmu pengetahuan. Kedua, lokakarya untuk pembinaan staf. Setelah sebuah buku pelajaran dan tulisan pendahuluan ditulis sesuai dengan 
aturan 1 sampai 12 di atas, maka diperlukan staf pengajar yang terlatih. Para ahli yang membuat produk tersebut harus bertemu para staf pengajar untuk mendiskusikan sekitar pra-anggapan tak tertulis, dampak-dampak tak terduga dari teori, prinsip dan pemecahan masalah yang dicakup buku tersebut. Selain itu, dalam pertemuan tersebut harus pula dijajaki sekitar persoalan metode pengajaran yang diperlukan untuk memahami buku-buku yang dimaksud, sehingga para staf pengajar dapat terbantu dalam upayanya mencapai tujuan akhir secara lebih efisien (al Faruqi, 1995: 118).

\section{Simpulan}

Program Islamisasi ilmu al Faruqi yang menekankan perombakan total atas keilmuan sosial modern Barat karena dianggap bersifat Eurosentris, tampak lebih utuh, jelas dan terinci dibanding gagasan islamisasi ilmu yang dilontarkan pemikir lain. Langkah-langkah islamisasi ilmu yang diberikan dan kritiknya terhadap realitas pendidikan Islam juga merupakan sumbangan besar dan bermanfaat bagi perombakan sistem pendidikan Islam. Namun, gagasan ini bukan tanpa persoalan. Ada beberapa hal yang perlu disampaikan.

Ketika Faruqi menyatakan bahwa salah satu tujuan islamisasi ilmu adalah untuk menentukan relevansi Islam pada setiap bidang ilmu pengetahuan (tujuan ketiga), muncul pertanyaan, sesungguhnya, Islam yang harus dibuat relevan dengan pengetahuan atau pengetahuan yang harus dibuat relevan untuk Islam?. Islam secara a-priori relevan untuk segala sesuatu (salih li kulli makan wa zaman). Tentang prinsip kesatuan kebenaran dan pengetahuan (prinsip ketiga). Jika 'kebenaran' dan 'pengetahuan' adalah satu dan sama, mencari pengetahuan berarti sama dengan mencari kebenaran. Persoalannya, apakah juga merupakan pencarian kebenaran jika seseorang meneliti teknik-teknik penyiksaaan, atau jika seseorang mencari data baru untuk menciptakan anthrax (bom kimia) dan senjata pemusnah massal yang lebih canggih, mengingat bahwa semua itu juga pengetahuan dan bermanfaat bagi yang menginginkannya?

Apa yang dianggap sebagai "kebenaran" dalam pengetahuan, sesungguhnya, bukan kebenaran yang hakiki (al haq) sebagaimana yang dipahami Faruqi. Kebenaran dalam pengetahuan tidak pernah dipakai dalam arti literalnya tetapi hanya dipakai dalam arti yang sangat terbatas. Tidak ada kebenaran yang sebenarnya, yang ada hanya beberapa kombinasi penglihatan atau pengamatan yang menurut pengalaman manusia terjadi dalam suatu urutan yang terbatas yang keteraturannya tepat sama setiap waktu, dan diduga dengan cara yang identik akan terjadi pada waktu yang akan datang dalam urutan terbatas yang 
sama (Quamar, 1983: 12).

Untuk bagian terbesar abad XX, benar bahwa kriteria objektif telah memberikan basis epistemologi bagi ilmu-ilmu alam maupun ilmu sosial. Akan tetapi, untuk masa sekarang, adalah kekeliruan jika ilmu-ilmu sosial dianggap mempunyai banyak kesamaan dengan ilmu-ilmu kealaman. Nilainilai dan objektifitas ilmu sosial telah berubah dan sangat didominasi oleh tradisi idealis. Tradisi-tradisi ini, mempunyai a-priori: (1) bahwa persepsi ternyata dibangun oleh kategori-kategori linguistik, sikap-sikap mental dan interes-interes pribadi pengamat, sehingga tidak benar-benar bersifat netral. (2) kategori-kategori, sesuai term-term mana pengalaman diorganisasikan, adalah refleksi dari nilai-nilai dan interes kelompok. (3) bahwa manusia tidak mengalami realitas sebagai sesuatu yang tak tertafsirkan, tetapi realitas tersebut dikonstruksi oleh skema konseptual (istilah Kant), ideologi (Marx), cagar bahasa (Wittgenstain), atau paradigma (Thomas Khunn) (Sardar, 1998: 50). Karena itu, apa sebenarnya yang dimaksud Faruqi dengan program spiritalisasi Islam pada disiplin-disiplin ilmu yang dibentuk oleh ideologi, bahasa dan paradigma masyarakat ini? Islamisasi ilmu atau justru westernisasi ilmu-ilmu Islam? Tegasnya, Islamisasi ilmu modern atau modernisasi ilmu Islam?

Bahwa displin-disiplin ilmu tidak diatur dan diprogram dari langit. Disiplin ilmu lahir dari matriks suatu pandangan dunia yang khusus, dan secara hirerkis selalu tersubordinasikan pada pandangan dunia tersebut. Disiplin-displin ilmu tidak mempunyai eksistensi otonom bagi dirinya sendiri melainkan berkembang menurut lingkungan historis dan kultural: yang khusus dan hanya mempunyai makna dalam pandangan dunia yang melahirkan dan mengevolusikannya. Pembagian ilmu ke dalam disiplin-disiplin yang ada sekarang adalah manifestasi khas dari peradaban Barat ketika merumuskan masalah-masalah yang dihadapi. Sebagai contoh, disiplin tentang orientalisme dikembangkan karena Barat menganggap Islam sebagai masalah untuk dipelajari, dianalisa dan dikuasi. Dengan demikian, menerima pembagian disiplin ilmu menurut epistemologi Barat seperti yang masih dilakukan Faruqi, sama artinya dengan mensubordinasikan pandangan-dunia Islam pada peradaban Barat. Artinya, Faruqi masih terjebak pada westernisasi khazanah Islam daripada Islamisasi ilmu.

\section{Daftar Pustaka}

Azra, Azyumardi, Pergolakan Politik Islam dari Fundamentalisme Modern hingga Post-Modernisme, (Jakarta, Paramadina, 1996). 
Basori, M., "Islamisasi Ilmu”, dalam HR Pelita, (ed. 24 Nopember 1991, No. XVIII/ 5450)

Faruqi dan Louis Lamya Faruqi, “Tauhid Dasar Peradaban Islam”, dalam jurnal Ulumul Qur`an, (no. 1/VII/ 1996)

Faruqi, Ismael R., Islamisasi Pengetahuan, terj. Anas Mahyudin, (Bandung, Pustaka, 1995)

Faruqi, Ismael R., Seni Tauhid, terj. Hartono, Yogyakarta, Bentang, 1999)

Faruqi, Ismael R., "Islamisasi Ilmu-Ilmu Sosial" dalam Abu Bakar Bagader (edit), Islam dalam Perpsektif Sosiologi Agama, (Yogyakarta, Titian Ilhi Press, 1996)

Faruqi, Ismael R., Tauhid, (Bandung, Pustaka, 1995)

Faruqi, Louis Lamya, Alaih Masa Depan kaum Wanita, terj. Masyhur Abadi, (Surabaya, alFikr, 1997)

Fauzi, Ihsan Ali, "Dibunuhnya alFaruqi Misteri Yang Akan Tetap Misteri" dalam majalah Umat, (No. 25, 10 Juni 1996), 48-57.

Hidayat, Kamaruddin \& Wahyuni Nafis, Agama Masa Depan Perspektf Filsafat Perenial, (Jakarta, UI Pres, 1995)

Iraqi, Athif, AlManhaj alNaqd fi Falsafah Ibn Ruysd, (Kairo, Dar alMaarif, 1990)

Jundi, Anwar, Islam Agama Dunia, terj. K. Suhadi, (Solo, Pustaka Mantiq, 1990)

Nassef, Abdullah Omar (ed), Social and Natural Sciences, The Islamic Perpective Ismael Raji alFaruqi, (Jeddah, King Abdulaziz University, 1981)

Nasution, Harun, Ensiklopedi Islam Indonesia, Vol. I, (Jakarta, Jambatan, 1992)

Pardoyo, Sekularisasi Dalam Polemik Sekapur Sirih Nurcholis Madjid, (Jakarta, Teprit, 1993)

Quamar, Jawaid, Tuhan dan Ilmu Pengetahuan Modern, terj. LPA IPB, (Bandung, Pustaka, 1983) 
Ridwan, Kafrawi, Ensiklopedia Islam, (Jakarta, Ikhtiar Baru Vanhouve, 1995)

Sardar, Ziauddin, "Islamisasi Ilmu Pengetahuan atau Westernisasi Islam", dalam Jihad Intelektual, terj. Priyono, (Surabaya, Risalah Gusti, 1998)

Soleh, Khudori, "Plus-Minus Pesantren \& PT" dalam HR. Bhirawa (Malang), 18 Juli 1996. 